\title{
DITADURA CIVIL-MILITAR, MEMÓRIA E TRAUMA: O TESTEMUNHO DE JOEL RUFINO DOS SANTOS (1941-2015)
}

\author{
Ana Júlia Pacheco ${ }^{1}$
}

\begin{abstract}
Resumo: O presente artigo propõe-se discutir o conjunto de narrativas testemunhais do historiador e escritor Joel Rufino dos Santos, que foi preso e torturado no início da década de 1970 devido a sua luta política contra a ditadura civil-militar instaurada por vinte e um anos no Brasil (1964-1985). Através de entrevistas concedidas pelo autor, que formam uma teia de lembranças que o singulariza como um testemunho sobrevivente ao regime, busco compreender as formas de expressão cunhadas pelo escritor, frente as (im)possibilidades de narrar experiências traumáticas como a tortura, empreendida durante esse período da história nacional por agentes do poder público.
\end{abstract}

Palavras-chave: Joel Rufino dos Santos. Ditadura civil-militar. Testemunho. Tortura. Memória.

\section{CIVIL-MILITARY DICTATORSHIP, MEMORY AND TRAUMA: THE TESTIMONY OF JOEL RUFINO DOS SANTOS}

\begin{abstract}
This article proposes to discuss the set of witness narratives from historian and writer Joel Rufino dos Santos, who was arrested and tortured in the early 1970s due to his political struggle against the civil-military dictatorship established for twenty-one years in Brazil (19641985). Through interviews by the author, that form a web of memories which singularizes it as a surviving testimony to the regime, I seek to understand the forms of expression coined by the writer, facing the (im)possibilities to narrate traumatic experiences like torture, undertaken during this period of national history by agents of the public power.
\end{abstract}

Keywords: Joel Rufino dos Santos. Civil-military dictatorship. A testimony. Torture. Memory.

\section{DICTATURE CIVILO-MILITAIRE, MÉMOIRE ET TRAUMATISME: LE TÉMOIGNAGE DE JOEL RUFINO DOS SANTOS}

Résumé: Cet article propose de discuter l'ensemble des récits de témoins de l'historien et écrivain Joel Rufino dos Santos, qui a été arrêté et torture au début des années 1970 en raison de sa lutte politique contre la dictature civilo-militaire établi depuis vingt et un ans au Brésil (19641985). À travers des interviews de l'auteur, qui forment une toile de souvenirs qui le singularise comme un témoignage survivant du régime, Je cherche à comprendre les formes d'expression inventées par l'écrivain, face aux (im)possibilites raconter des expériences traumatiques comme la torture, entrepris au cours de cette période d'histoire nationale par des agents du pouvoir public.

Mots-clés: Joel Rufino dos Santos. Dictature civilo-militaire. Témoignage. La torture. La mémoire.

\footnotetext{
${ }^{1}$ Doutoranda em História pela Universidade Federal do Rio Grande do Sul (UFRGS). Possui Mestrado em História pela UFRGS (2018) e Graduação (Licenciatura e Bacharelado) em História pela Universidade do Estado de Santa Catarina (2015). Leciona em regime ACT pela Secretária de Educação do Estado de Santa Catarina (SED-SC). É Pesquisadora Associada ao Núcleo de Estudos Afro-Brasileiros da Universidade do Estado de Santa Catarina (NEAB/UDESC). Atua como Assistente Administrativo da Associação Brasileira de Pesquisadores/as Negros/as (ABPN) e Chefe de Edições da Revista da ABPN. Tem experiência na área de História, atuando principalmente nos seguintes temas: história do Brasil, história da África e da Diáspora e seu ensino, relações étnico-raciais e diversidade.
} 


\section{DICTADURA CIVIL-MILITAR, MEMORIA Y TRAUMA: EL TESTIMONIO DE JOEL RUFINO DOS SANTOS}

Resumen: Este artículo propone discutir el conjunto de narraciones de testigos del historiador y escritor Joel Rufino dos Santos, quien fue arrestado y torturado a principios de la década de 1970 debido a su lucha política contra la dictadura civil-militar establecido por veintiún años en Brasil (1964-1985). A través de entrevistas del autor, que forman una red de recuerdos que lo singulariza como un testimonio sobreviviente del régimen, busco comprender las formas de expresión acuñadas por el escritor, frente a las (im)possibilidades para narrar experiencias traumáticas como tortura realizado durante este período de la historia nacional por agentes del poder público.

Palabras clave: Joel Rufino dos Santos; Dictadura civil-militar; Testimonio; La tortura; Memoria.

\section{Introdução}

No limiar de sua recente história republicana, o Brasil experienciou a partir do ano de 1964, em contexto similar com outras sociedades latino-americanas, a instauração de uma ditadura civil-militar que perdurou por 21 anos.

O novo governo instituído por um golpe do movimento militar que derrubara o então presidente João Goulart, passou a construir um projeto de organização social para o país baseado, segundo Maria José de Rezende (2013), num sistema de ideias e valores sedimentadas sobre um suposto ideário de democracia, estritamente vinculado às suas estratégias de ação nas esferas econômica, política e psicossocial.

A atuação de seus condutores intensificou o intercondicionamento entre o processo econômico e o processo político, "por ser um processo de força, que tornava o processo político opaco, com a imprensa sob censura, inclusive no terreno da economia" (SINGER, 2014, p. 199). Ao mesmo tempo, buscou legitimidade e reconhecimento em diversos segmentos sociais, fossem grupos, instituições ou indivíduos; e na dimensão social, houvera um empenho em empregar valores ligados à família, à religião, à pátria, à ordem e à disciplina. Elementos estes, que, na ótica dos governos militares, seriam socialmente fundantes da nova ordem político-cultural brasileira.

Não obstante, o universo alheio aos limites desta relação de identificação estava sujeito ao controle, à repressão e até à eliminação. O regime só admitia "aquilo que estava absolutamente integrado ao seu controle num processo de geração contínua de uma ampla consonância com seus propósitos nas diversas esferas da vida social" (REZENDE, 2013, p. 4-5). As décadas de 1960 e 1970 marcaram gravemente o cenário social brasileiro, com a utilização institucionalizada da violência, da censura, da repressão, da tortura, bem como assassinatos e desaparecimentos forçados. 
Passados quase 30 anos do final da ditadura, em 2014, a Comissão Nacional da Verdade (CNV), um colegiado constituído a fim de apurar as denúncias de violações de direitos humanos, entre 1946 e 1988, criada pela Lei 12.528/2011 e instituída em maio de 2012 no governo de Dilma Rousseff, publica seu relatório em três volumes ${ }^{2}$. O documento tornou público a identificação das graves violações de direitos humanos praticadas pelo governo brasileiro, leia-se prisão ilegal e arbitrária, tortura, morte ou desaparecimento forçado, "evidenciando-se durante a ditadura militar um contexto sistemático de violações de direitos humanos” (BRASIL, 2014, p. 28).

A CNV confirmou 434 mortes e desaparecimentos de vítimas do regime civilmilitar, salientando que esses números possivelmente não correspondem ao total de mortos e desaparecidos, mas somente os casos cuja comprovação foi possível em função do trabalho realizado pela equipe. Fruto de suas atividades de pesquisa, baseadas em evidências obtidas através de órgãos públicos, entidades da sociedade civil, vítimas e seus familiares, a comissão concluiu que durante os governos militares, a repressão e a eliminação de opositores políticos se converteram em política de Estado, concebida e implementada a partir de decisões emanadas da presidência da República e dos ministérios militares.

Enquanto um acontecimento recente, o regime civil-militar operou na trajetória política brasileira deixando marcas e feridas que se encontram abertas. Testemunhas que se opuseram à ordem vigente do período estão vivas, somadas a existência numerosa de arquivos sobre a repressão ${ }^{3}$. Estes sujeitos, seus corpos, suas vozes e histórias, cumprem um papel importante no desenvolvimento da pesquisa historiográfica sobre o tema, cuja memória emerge como o principal elemento para a constituição de depoimentos que reconstroem o passado. Ao mesmo tempo, seus relatos evocam traumas decorrentes de interrogatórios, prisões, tortura e sequestros, e contribuem também para estimular uma dada reconciliação entre o passado e o presente.

Memórias de testemunhos de sobreviventes ao regime, como a do historiador e escritor Joel Rufino dos Santos, preso e torturado no início da década de 1970 devido a sua luta política, revelam as sequelas psicológicas deixadas pelas ações do estado de exceção. Ao recordar e narrar uma experiência traumática singular, o testemunho

\footnotetext{
${ }^{2} \mathrm{O}$ relatório está disponível em <http://cnv.memoriasreveladas.gov.br/>. Acesso em: 25 jul. 2019.

${ }^{3}$ O projeto "Brasil Nunca Mais" reuniu, por exemplo, o exame de cerca de 850 mil páginas de processos judiciais movidos contra presos políticos. A publicação retrata as torturas e outras graves violações aos direitos humanos durante a ditadura civil-militar brasileira, comprovadas a partir do uso de documentos oficiais do próprio Estado, que institucionalizou a tortura como ferramenta de investigação e repressão nesse período. $\mathrm{O}$ projeto e seu acervo podem ser consultados em http://bnmdigital.mpf.mp.br/pt-br/. Acesso em: 27 jun. 2019.
} 
assume estratégias de narração circunscritos em suas falas, apropriando-se de e ressignificando sentidos e subjetividades do evento testemunhado.

O relato do intelectual Joel Rufino dos Santos oferece proveitosas possibilidades de reflexão sobre a relação da testemunha que vivenciou um trauma, evidenciando o entrelaçamento e a busca de uma harmonização entre passado, presente e futuro, bem como a reavaliação de valores à condição humana.

Para tanto, utilizo, neste estudo, quatro entrevistas e um depoimento publicados entre os anos de 2008 a 2015, disponíveis eletronicamente ${ }^{4}$, em que o entrevistado rememora a experiência da prisão e da tortura. Dialogando com a bibliografia que entrelaça as temáticas de memória, trauma e testemunho, examino sua narrativa testemunhal com o objetivo de compreender as formas de expressão cunhadas pelo escritor, frente as (im)possibilidades de narrar a experiência de um trauma, a tortura, empreendida por agentes públicos das forças de segurança durante a ditadura civilmilitar.

\section{Uma breve biografia}

Professor, historiador e escritor carioca, Joel Rufino dos Santos é conhecido nacionalmente por suas obras no campo da Literatura e da História que envolvem as temáticas de cultura africana e afro-brasileira, igualmente por seu pensamento e atuação na militância política, especialmente contra a ditadura e o racismo no Brasil ${ }^{5}$.

Nascido em 1941 em Cascadura, subúrbio do Rio de Janeiro, o professor iniciou a carreira acadêmica com a formação no curso de História pela extinta Faculdade de Filosofia da Universidade do Brasil. Ainda estudante, trabalhava como professor do Instituto Superior de Estudos Brasileiros (ISEB) e assistente do escritor, historiador e político brasileiro Nelson Werneck Sodré, sendo coautor da obra "História Nova do Brasil”, conhecida por seu marco historiográfico, ao revisar em profundidade a história brasileira, publicada em março de 1964 pela Campanha de Assistência ao Estudante (Cases) e dirigida por Sodré.

Com a deflagração do golpe civil-militar em 1964, iniciou militância política por meio do Partido Comunista Brasileiro (PCB). Neste mesmo contexto, a coleção "História Nova do Brasil" foi considerada "subversiva", e seus autores foram presos ou

\footnotetext{
${ }^{4}$ No decorrer do artigo informo as fontes de acesso de cada entrevista utilizada.

${ }^{5}$ As próximas informações, discorridas nesta parte do texto, foram colhidas no site dedicado à memória de Joel Rufino dos Santos, disponível em: http://joelrufinodossantos.com.br/paginas/biografia.asp. Foram cruzadas informações contidas no site, as entrevistas concedidas pelo escritor nos portais de notícias e em artigos acadêmicos que exploraram as produções do escritor.
}

Revista Escritas do Tempo - v. 1, n. 2, jul-out/2019 - p. 75-89 
exilados $^{6}$; Joel Rufino, perseguido como tantos outros jovens intelectuais da época, se exila na Bolívia, atuando como jogador profissional do Fútbol Club Bolívar, encerrando sua carreira no esporte ao mudar-se para o Chile.

O professor volta ao Brasil no ano de 1967, vivendo clandestinamente e contribuindo com a Ação Libertadora Nacional (ALN) ${ }^{7}$ até ser preso em dezembro 1972 quando foi condenado a oito anos de prisão pela Justiça Militar, onde cumpriu dois anos em regime fechado e foi solto sob condicional.

Joel Rufino dos Santos retomou a carreira acadêmica durante a década de 1980, atuando de modo geral na luta em defesa dos Direitos Humanos. Autor diversamente premiado, produziu narrativas que aliaram os elos da História e da Literatura, lançando dezenas de obras literárias de ficção e não-ficção, escrevendo extensamente romances e literaturas infanto-juvenis, sempre atentos para a reflexão sobre a questão racial e as culturas negras no Brasil ${ }^{8}$.

Com a aprovação da Lei da Anistia em 1979, foi reintegrado e convidado a dar aulas na graduação na Escola de Comunicação e na Faculdade de Letras da atual Universidade de Federal do Rio de Janeiro (UFRJ), onde atuou por 20 anos. Na mesma instituição, obteve ainda os títulos de "Notório Saber e Alta Qualificação em História" e "Doutor em Comunicação e Cultura".

Em 2015, quando ocupava o cargo de Diretor Geral de Comunicação e de Difusão do Conhecimento no Tribunal de Justiça do Estado do Rio de Janeiro, Joel Rufino dos Santos faleceu no dia quatro de setembro por complicações decorrentes de uma cirurgia cardíaca.

\footnotetext{
${ }^{6}$ Vanessa Clemente Cardoso (2016) ressalta que a obra criticava a historiografia tradicional apresentada nos manuais escolares utilizados no Brasil e, ao mesmo tempo, objetivava uma inovação no seu conteúdo, possuindo uma dimensão política. Suas páginas apresentavam a necessidade de reformas sociais, em especial no plano educacional, enquadrando-se no prospecto político que o país vivenciava durante o governo João Goulart. Contudo, com a instauração do regime civil-militar, os volumes da História Nova foram queimados e proibidos e seus autores tornaram-se alvo de perseguição.

${ }^{7}$ A Ação Libertadora Nacional (ALN) foi uma organização revolucionária criada em 1968 por Carlos Marighella, Joaquim Câmara Ferreira e Virgílio Gomes da Silva, dissidentes do Partido Comunista Brasileiro (PCB). Ao lado do Movimento Revolucionário 8 de Outubro (MR-8) e do Partido Comunista Brasileiro Revolucionário (PCBR), foi um dos principais grupos que, entre as décadas de 1960 e 1970, se dedicaram à guerrilha no país, defendendo a necessidade da luta armada para derrubar o regime civilmilitar instaurado no Brasil.

${ }^{8}$ Algumas obras mais expressivas do autor: Épuras do social: como podem os intelectuais trabalhar para os pobres. São Paulo: Global, 2004; Assim foi se me parece: livros, polêmicas e algumas memórias. Rio de Janeiro: Rocco, 2008; Atrás do muro da noite: dinâmica das culturas afro-brasileiras. Brasília: MINC / Fundação Cultural Palmares, 1994. (coautoria Wilson dos Santos Barbosa). História política do futebol brasileiro. São Paulo: Brasiliense, 1981; O que é racismo. São Paulo: Brasiliense, 1982; Gosto de África. São Paulo: Global, 1998; O caçador de lobisomem, ou, o estranho caso do cussaruim da Vila do Passavento. São Paulo: Abril Cultural, 1975; Claros sussurros de celestes ventos. Rio de Janeiro: Bertrand Brasil, 2012. Quando eu voltei, tive uma surpresa. Ed. Rocco, 2000.
}

Revista Escritas do Tempo - v. 1, n. 2, jul-out/2019 - p. 75-89 


\section{"É uma experiência limite": o testemunho de Joel Rufino dos Santos}

Na história humana, os testemunhos de eventos traumáticos se manifestam de diferentes formas e em diferentes locais, se utilizando de recursos narrativos para reconstituírem na forma de relatos situações consideradas, em princípio, como irrepresentáveis e inenarráveis.

No Brasil, conforme salienta o historiador Carlos Fico (2012, p. 44) a Ditadura civil-militar pode ser pensada em conjunto com outros "eventos traumáticos", característicos em países que viveram totalitarismos, ditaduras militares, o apartheid e extermínios ao longo do século XX, pois se trata de um processo histórico que envolveu grande dose de violência, sobretudo a prisão arbitrária de pessoas, seguida quase sempre de tortura e, várias vezes, de morte.

O próprio conceito de testemunho, cuja origem da noção é jurídica, vem constantemente sendo rediscutido. Na tradição crítica do campo de estudos literários no Brasil, o debate envolvendo obras literárias lusófanas e hispano-americanas aflora frequentemente tensões que motivam a reflexão sobre seus fundamentos. Conforme aponta o crítico literário Jaime Ginzburg (2008, s/p), a escrita do testemunho não se restringe apenas ao depoimento direto, pois passa por elaboração atenta dos recursos de linguagem que evidenciam uma ambiguidade: a necessidade de narrar o que foi vivido e a percepção de que a linguagem é insuficiente para dar conta do que ocorreu.

Se apresentando como condição de sobrevivência, o testemunho caracteriza-se, segundo Márcio Seligmann-Silva (2008, p. 66), como uma atividade elementar. Para o teórico, a narrativa é dependente da situação radical de violência, desencadeando uma carência absoluta de narrar. Evocando a obra É isto um homem, do escritor italiano sobrevivente ao Shoah Primo Levi (1988), Seligmann-Silva aponta que sua narrativa, ao reunir a circulação das imagens do campo de concentração, se inscreveram como uma queimadura na memória do sobrevivente. Na medida em que são, aos poucos traduzidas, transpostas para "os outros", permite que ele inicie seu trabalho de religamento ao mundo, de reconstrução da sua casa. "Narrar o trauma, portanto, tem em primeiro lugar este sentido primário de desejo de renascer" (SELIGMANN-SILVA, 2008, p. 73).

$\mathrm{Na}$ perspectiva do autor, deve-se levar em conta que o "O testemunho é uma modalidade da memória" (2008, p. 73), que traduz dilemas oriundos da confluência entre a tarefa individual da narrativa do trauma e de sua componente coletiva. Nas “catástrofes históricas", como nos genocídios ou nas perseguições violentas de 
determinadas parcelas da população, segundo ele, a memória do sobrevivente é sempre uma busca de compromisso entre o trabalho de memória individual e social.

No caso de sobreviventes da ditadura civil-militar, segundo Mariluci Cardoso de Vargas (2018, p. 26), a aparição do testemunho durante o contexto de transição e redemocratização do cenário político brasileiro, foi impedida sua dimensão acusatória ou contribuinte para a persecução penal. Por outro lado, como palavra que resiste à realidade, o testemunho subsistiu à falta de escuta jurídica e criou vias alternativas para sua expressão, gerando produções refletidas em publicações literárias e entrevistas em audiovisuais concedidas para filmes documentários ${ }^{9}$.

Dada a sua produção e atuação no campo da História, Literatura e Educação, a figura e a trajetória de Joel Rufino dos Santos são reconhecidas nacionalmente. Nas entrevistas concedidas pelo escritor é possível constatar, ainda que acanhadamente, perguntas que permeiam sua experiência na luta contra a ditatura civil-militar brasileira, com escritos referentes às suas memórias quanto ao exílio, à prisão e à tortura.

As entrevistas do historiador sobrevivente localizam-se no mesmo contexto de outros testemunhos vítimas de violência e violações dos Direitos Humanos. A cientista política Maria Paula Araújo (2015) afirma que nos últimos anos o testemunho oral tem sido usado em todas as Comissões de Verdade instaladas nos países que vivenciam contextos de transição democrática, posteriores a períodos de violência e repressão institucionalizada. Essa política favoreceu o trabalho e a produção de depoimentos coletados por historiadores e antropólogos transcritos e publicados com o objetivo político de denúncia e reparação.

Os depoimentos e testemunhos são coletados, registrados e divulgados com base na noção de violação de direitos humanos que, por sua vez, baseia-se na noção de individuo, tal como formulada pela filosofia e pela ciência política ocidental: um sujeito universal, racional e livre, portador de direitos e de uma individualidade única. (ARAUJO, 2015, p. 1)

As falas de Joel Rufino dos Santos estão conectadas a esse cenário. O intelectual também irá contribuir com depoimento para a Comissão da Verdade do Estado de São Paulo - Rubens Paiva, no relatório localizado na seção temática específica denominada Perseguição à População e ao Movimento Negros, publicado em março de 2015.

\footnotetext{
${ }^{9}$ No caso de estudo da pesquisadora, foram analisadas produções literárias, cinematográficas, artísticas e acadêmicas produzidos pelas/os filhas/os de resistentes à ditadura civil-militar, que expressavam suas identidades e afirmavam ou negavam as heranças das experiências extremas vividas por elas ou por seus pais. Sua tese (2018) analisa essas produções, buscando entender e cunhar as formas de expressão do testemunho de situações-limite e experiências extremas provocadas pela conjuntura ditatorial.
} 
Antes disso, contudo, o autor já havia tocado nas memórias do passado quanto a sua experiência durante a ditadura civil-militar em algumas entrevistas concedidas, que narram lembranças marcadas por subjetividades, sentimentos e sensações. Tais entrevistas não foram efetuadas no sentido de investigar ou colher o depoimento do testemunho, sendo mais gerais e centradas na atuação, na inspiração e na produção do intelectual negro. Não obstante, a temática evocando o sobrevivente da repressão foi, por vezes, brevemente tocada nas entrevistas, onde Rufino pode narrar suas memórias.

No ano de 2008, em entrevista dada ao jornalista Luciano Trigo, do Portal G1, sobre o lançamento de sua obra memorialística Assim foi (se me parece), Joel é primeiramente perguntando ao autor em que medida existe ficção nas suas memórias:

O título Assim foi (se me parece) já sugere que não creio em memória "verdadeira". Há uma diferença, uma lacuna entre falar e dizer, aí se instala a memória. Os fatos que relato aconteceram, mas para outros que os viveram significaram outras coisas. Mesmo os livros de História andam cheios de ficção, no sentido em que todo relato introduz uma subjetividade. Com mais razão ainda num livro como o meu. (SANTOS, 2008, s/p)

Não se isentando, Rufino, um intelectual e crítico, parece possuir absoluta clareza das possibilidades e dos limites da memória. No exercício de rememorar não há como o indivíduo lembrar-se de tudo o que ocorreu, podendo deixar certos acontecimentos de fora e elevar outros, e igualmente, a memória também pode atualizar e presentificar o passado, uma vez que é a experiência existencial integrada ao cotidiano, através da narrativa, que fornece significado a eventos vividos e ressignifica outros. Na perspectiva da historiadora Lucilia de Almeida Neves Delgado (2003, p. 1516), apreender a amplidão do passado é um desafio para o ser humano, ativar a memória também o é, "pois a memória, além de incomensurável, é mutante e plena de significados de vida, que algumas vezes se confirmam e usualmente se renovam”.

$\mathrm{Na}$ mesma entrevista, abordando a vida, as obras e as influências do escritor, o entrevistador pergunta sobre sua experiência na prisão. Joel Rufino responde associando os eventos de tortura que causaram a morte de alguns companheiros também presos, relatando brevemente sua própria prisão, onde transcorre o trauma vivido: "Tive o meu quinhão de socos e choques elétricos, mas não conheci o pior, a 'cadeira do dragão'. É uma experiência inenarrável, no limite do humano. Quem a experimentou, em si ou nos companheiros, não sabe dizer qual é a natureza do torturador" (SANTOS, 2008, s/p).

Inumeráveis são os impactos subjetivos causados pela experiência traumática daquelas que narram. Elielson Figueiredo (2015, p. 105) salienta que a reconstrução 
mnemônica dos espaços de tortura e de encarceramento resiste ao esquecimento e atualiza, para quem narra, as vivências físicas e psicológicas da tortura, em que a narrativa do testemunho descreve os horrores imputados até os espasmos e desfalecimentos, "[n]uma tentativa permanente de reconciliar corpo e linguagem, separados irreversivelmente pelo trauma imposto à integridade do ser".

Em 2010, numa extensa entrevista concedida a Revista Democracia Viva do Ibase, de cunho mais pessoal, que explora diversas dimensões e temporalidades da sua vida, Joel Rufino dos Santos respondeu longamente à pergunta: É possível dimensionar o impacto das torturas que sofreu na sua vida?, suscitando três aspectos. O primeiro diz respeito aos sentidos do torturado sobre a tortura e o torturador; o segundo exprime a culpa sentida por conta da delação de companheiros, e por último das sequelas e da possibilidade de cura frente ao sofrimento causado pela tortura. Vejamos nos trechos resumidos a seguir:

dos presos políticos que conheci que passaram por tortura, grosso modo, dividiam-se em dois grupos. Um grupo achava que a tortura, que o torturador, são desumanos, que não são gente, que são monstros ou algo parecido; e o outro grupo achava que, apesar de ser uma forma extrema de crueldade, uma experiência-limite, o torturador é humano e que, dependendo das circunstâncias, uma pessoa que não torturaria, tortura.

quem passou pela tortura, quase certamente denunciou alguém, levou à queda de alguém. Mesmo aqueles que morreram sob tortura, eventualmente, podem ter entregado alguém, o que não os livrou de morte. [...] durante algum tempo, me puni muito por ter entregado algumas pessoas. E só me recuperei, cumprindo pena por alguns meses depois, conforme retomei o processo de luta como preso político. O preso político, mesmo ali naquelas condições carcerárias, tem condição de lutar, de prosseguir a sua luta de alguma maneira. [...]

Vamos falar das sequelas desse sofrimento. Esse sofrimento de ter entregado algumas pessoas, penso quase ter me curado por conta disso, porque não desisti de lutar, continuo lutando, de alguma maneira, continuo comunista. Isso, então, me cura, ou quase, dessa sequela. Agora, há sequelas dificílimas, talvez impossíveis de se curar. Por exemplo, ter visto alguém morrer sob tortura ou ter visto alguém ser torturado barbaramente, uma pessoa jovem (SANTOS, 2013, p. 27).

Como apontaram Luciana Chociay e Claudia Monteiro (2013, p. 91), o trauma pode ser considerado uma ferida na memória, tanto dos militantes como de seus familiares, que também passaram por momentos traumáticos. Para as pesquisadoras, o testemunho, como portador da memória, traz consigo emoções que o acontecimento narrado trouxe para si, onde a memória serve como retenção do acontecido, tornando-se "um objeto essencial para a denúncia desse fato histórico para uma reparação moral”. 
As palavras de Joel Rufino, um sobrevivente da repressão, “devolvido" à vida cotidiana, tornam-se dolorosas ao relembrar o sofrimento vivido. Poder narrar abertamente lhe parece um recurso oportuno para denunciar os crimes de tortura, colocando-o numa condição de sobrevivência, onde, ao mesmo tempo, o escritor estabelece uma ligação com os outros na medida em que os acontecimentos descritos atingem aspectos do campo sentimental e moral.

Em suas falas, há sempre a procura de uma possível reconciliação consigo mesmo e com seu passado, num exercício de compreensão do presente, que o levou, nas últimas quatro décadas, a lutar de forma engajada na área social e política, através do campo intelectual e educacional no Brasil. Sobre isso, convém entender que, na ótica do testemunho, "A linearidade da narrativa, suas repetições, a construção de metáforas, tudo trabalha no sentido de dar esta nova dimensão aos fatos antes enterrados." (SELIGMANN-SILVA, 2008, p. 69).

No mesmo ano, concedendo entrevista aos historiadores Amauri Mendes Pereira, Amilcar Araujo Pereira e Verena Alberti, para a Revista Estudos Históricos, Joel Rufino novamente relata a tortura sofrida, destacando o papel da culpa e da vergonha relacionado à delação. O escritor responde à pergunta: Qual a sua memória? o que passa, quando você lembra? [com relação ao episódio da tortura].

Bom, primeiro, eu acho que é inenarrável. Não dá para narrar, que você só experimenta quando está para morrer. A sensação é essa. Chega uma altura que não faz mais diferença viver ou morrer. Se morrer é melhor - você chega a pensar isso. Mas quando você não morre, você se culpa por não ter morrido. Esse é um problema do torturado. Porque, se você sobreviveu, alguma coisa você falou. Seja mentira, seja verdade, seja para enganar os torturadores, foi alguma coisa que você falou que livrou a sua cara. E você aí, depois, fica: "Eu não devia ter falado, devia ter morrido". Isso acompanha você durante um tempo. E passam anos e você parece que não esquece nunca. Você não consegue superar, tirar aquilo de dentro de você (SANTOS, 2013, p. 506).

Observa-se, no testemunho do professor, a tentativa de construir uma coerência e uma continuidade ao narrar sua experiência traumática, marcada, como ele nos informa nas entrevistas, por muitas rupturas. O esquecimento não aparece como opção para sua redenção, pois, suas experiências, ao serem contadas no âmbito do individual, como a memória de um sobrevivente do regime civil-militar, também são conectadas às de outros sujeitos, apresentando uma dimensão coletiva da repressão.

Companheiros, colegas, pessoas com quem conviveu naquele período, também vítimas da violência, são constantemente evocados nas lembranças do narrador, em tom de respeito, saudade, pesar e culpabilidade. Condizente com impactos do trauma no 
testemunho, Dominck LaCapra (2005, p. 63) aponta que "El trauma es una experiencia que trastorna, desarticula el yo y tenera huecos en la existencia; tiene efectos tardíos imposibles de controlar sino con dificultad $y$, tal vez, imposibles de dominar plenamente".

Numa outra entrevista, em audiovisual, concedida ao Grupo Editorial Global, em 2014, o escritor se reconhece como partícipe da "geração de classe média intelectual" que sofreu a ditadura. Em sua visão, a ditadura civil-militar foi sobretudo um "sistema de tortura" angariado por uma política de Estado. Ao refletir sobre a experiência individual da tortura, afirma que este é "o horror máximo que você pode se submeter, que você pode passar na vida". Narra, ainda, que para além da violência sofrida, também viu outros colegas serem torturados e mortos.

Rufino, ao buscar resiliência no passado traumático, questiona-se se o horror e o sofrimento individual causados pelo próprio governo, possibilitaram "salvar", mudar e melhorar a sociedade. Na contemporaneidade, segundo o autor, a população pobre e negra da sociedade brasileira ainda experiencia o horror da tortura pela polícia brasileira: "o que veio depois da ditadura, se parece muito com a ditadura [...] é um paradoxo". Os governos progressistas e avançados, em muitos pontos foram importantes, mas não realizaram reformas estruturais, como a reforma agrária, a reforma urbana, a reforma econômica e a reforma do funcionamento político.

Nas falas do intelectual, a tortura parece ser o aspecto principal e mais evocado do passado, contextualizado nos governos militares. Ao narrar sobre o assunto traumático, Rufino fornece informações técnicas, expressadas por meio de emoções e significados do acontecimento em sua vida, articulando-o sempre com o cenário político e a conjuntura governamental daquele momento, e igualmente, assimilando-o com outras experiências comuns às suas, numa dimensão coletiva, rememorada ao citar companheiros. Joel Rufino dos Santos procura, sem sucesso, um oásis nos dados atuais de violência no país, como um recurso apaziguador da sua experiência. A ditadura, para ele, nunca acabou, pois, a tortura e a violência continuam sinônimos dela, mesmo em regimes democráticos do presente.

Relacionando com esse aspecto, Danielle Tega (2005) afirma que um trauma não se limita apenas como registro do passado, mas como um registro da força de uma experiência que ainda não está totalmente apreendida:

A capacidade de recuperar o passado é, paradoxalmente, vinculada à incapacidade de acessá-lo, indicando que aquilo que retorna não é simplesmente

Revista Escritas do Tempo - v. 1, n. 2, jul-out/2019 - p. 75-89 
uma experiência avassaladora que foi obstruída por uma repressão tardia ou pela amnésia, mas um evento que foi parcialmente constituído pela sua falta de integração na consciência. Por não haver sido plenamente integrado no modo como ocorreu, o evento traumático tampouco pode se tornar uma espécie de memória narrativa associada a uma história acabada do passado (TEGA, 2015, p. 2).

Por outro lado, é possível verificar mais enfaticamente, a componente coletiva na experiência traumática vivenciada por Joel Rufino dos Santos, no último documento colhido para análise. Em Depoimento: um flash do negro sob a repressão da ditadura, localizado no item 4 da seção intitulada Perseguição à população e ao movimento negros, contida no Relatório Comissão da Verdade do Estado de São Paulo "Rubens Paiva”, Tomo I - Parte II - Perseguição à População e ao Movimento Negros, o escritor participa ativamente de um projeto coletivo para documentar as graves violações dos direitos humanos realizadas no estado de São Paulo.

O capítulo que o historiador contribui com o depoimento constitui espaço específico do relatório para dar destaque a presença negra no movimento de combate ao regime civil-militar. Rufino apontou nessa obra que, dentre os mortos e os desaparecidos, figuram nomes de militantes de origem negra, e que por serem maioria entre os mais pobres, os negros eram os maiores atingidos pelas políticas autoritárias do período. Ainda, salienta o relatório, que "não se pode deixar de considerar que a população pobre e negra é atingida até os dias de hoje com práticas instauradas no período" (2015, s/p).

Em consonância com a proposta da Comissão da Verdade do Estado de São Paulo "Rubens Paiva", o depoimento, de cinco páginas, de Joel Rufino dos Santos é orientado conforme sua tematização: a população negra. Nele, o escritor vai descrevendo eventos, cenários, situações com pessoas identificadas negras onde ele testemunhou situações de discriminação e racismo, finalizando que:

Este depoimento não está à altura do que seu autor gostaria de dar. Se o desse com menos idade, com mais energia e saúde, emergiriam outros fatos significativos do racismo (ou do que nos habituamos a chamar assim) na repressão aos que lutaram contra a ditadura. Já esqueci muito, embora não tenha superado as sessões de choque, em mim e na minha mulher na época, despidos para acentuar a solidão, os gritos e gemidos das noites infernais, os revólveres engatilhados em nossas cabeças, a morte de jovens como nós, seus choros, gritos e excrementos, suas palmas como troncos produzidos por palmatórias furadas. (SANTOS, 2015, p. 31)

LaCapra (2008) salienta a existência de traumas que foram assumindo significados para um determinando grupo ou comunidade, traumas que até receberam a 
função e a capacidade de sustentar uma identidade. Nesse depoimento, podemos observar a atuação da memória na reconstrução de episódios do passado, representada na forma de uma experiência de memória coletiva. A violência narrada é apresentada no depoimento como uma violência que se abateu sobre todo um povo, o povo negro.

Joel Rufino opta por dar uma função prática ao passado traumático: narrar para ajudar a reconstruir e a compreender parte da história do Brasil recente, fazendo jus à memória, à verdade e à justiça. Seu corajoso exercício de discorrer sobre o irrepresentável, bem como o de outros sobreviventes "gera possibilidades de estudo e ao mesmo tempo pode proporcionar alivio ao depoente ao expor para a sociedade as torturas cometidas, de modo a proporcionar justiça a ele e aos que também foram torturados durante o Regime Militar" (CHOCIAY; MONTEIRO, 2013, p. 89).

\section{Considerações Finais}

O testemunho traz para o historiador, mais do que relatos objetivos e empíricos, a experiência subjetiva dos depoentes (ou narradores), no caso a experiência do trauma e da violência política. (ARAUJO, 2015, p. 2)

Em consonância com a afirmação evocada na citação, este artigo buscou apresentar e enfatizar as estratégias e as formas de expressão utilizadas por um testemunho diante das (im)possibilidades de narrar uma experiência traumática: a tortura. Através da memória de Joel Rufino dos Santos - perseguido, preso e torturado durante o regime civil-militar brasileiro -, contida nas entrelinhas de entrevistas concedidas pelo escritor, observamos nuances, tramas e sentidos do intelectual ao narrar as experiências violentas sofridas no passado.

Embora muito brevemente, Rufino pode transitar em suas falas, conteúdos relacionados a militâncias, resistências, prisão e exílio, autocrítica, relacionamentos, perdas e derrotas, tortura e morte, acompanhado, por vezes, de vergonha, saudade e pesar. Suas experiências, seu passado vivido, assim como a de muitos outros testemunhos, são inexprimíveis devido à dimensão do trauma gerado. Os caminhos escolhidos, as lembranças silenciadas, relevâncias, omissões, ênfases, ressignificações das experiências vividas, podem ser, em muitas ocasiões, soluções para tentar construir uma vida digna, novamente humana, isenta de culpa, medo ou sofrimento.

$\mathrm{Na}$ contemporaneidade e no seio dos regimes e das instituições democráticas, o testemunho desempenha um papel decisivo. Sua presença e voz na constituição das instituições democráticas possibilitam o acesso à informação, que por sua vez é uma ferramenta vital para a elucidação das atrocidades do passado e, consequentemente, em 
uma condição necessária para a obtenção da verdade, reparação das vítimas, e a recuperação da memória histórica (BRASIL, 2014, p. 39).

\section{Referências}

ABREU, Alzira Alves de. Ação Libertadora Nacional (ALN). In: ABREU, Alzira Alves de et al (coords.). Dicionário Histórico-Biográfico Brasileiro - Pós-1930. Rio de Janeiro: CPDOC, 2010.

ARAÚJO, Maria Paula. Testemunho, memória, reparação. A diversidade de subjetividades: questões teóricas e políticas. Anais do XI Encontro Regional Sudeste de História Oral. Dimensões do público: Comunidades de sentido e narrativas políticas, 08 a 10 de julho de 2015 .

BRASIL, Comissão Nacional da Verdade. Mortos e desaparecidos políticos. Brasília: CNV, 2014.

CARDOSO, Vanessa Clemente. A polêmica História Nova do Brasil: um projeto de vanguarda derrotado politicamente. História \& Ensino, Londrina, v. 22, n. 1, p. 127 154, jan./jun. 2016.

CHOCIAY, Luciana; MONTEIRO, Claudia. Reflexões sobre Memória e Testemunho a partir do Livro Brasil: Nunca Mais. Revista TEL - Tempo, Espaço, Linguagem, v. 4, n. 01 - jan.- abr. 2013.

DELGADO, Lucila de Almeida Neves. História oral e narrativa: tempo, memória e identidades. História Oral, n. 6, p. 9-25, 2003.

FICO, Carlos. História do Tempo Presente, eventos traumáticos e documentos sensíveis o caso brasileiro. Varia Historia, Belo Horizonte, v. 28, n. 47, p.43-59, jan/jun 2012.

FIGUEIREDO, Elielson. Corpos para não esquecer: o testemunho e a cena da tortura. Margens - Revista Interdisciplinar. Dossiê: Literatura e Resistência, v.9. n. 13. dez 2015.

GINZBURG, Jaime. Linguagem e trauma na escrita do testemunho. Conexão Letras, v. 3, n. 3, 2008.

LACAPRA, Dominick. Escribir la historia, escribir el trauma. Buenos Aires: Nueva Visión, 2005.

REZENDE, Maria José de. A ditadura militar no Brasil: repressão e pretensão de legitimidade: 1964-1984 [livro eletrônico] Londrina: Eduel, 2013.

SANTOS, Joel Rufino dos. Entrevista: Joel Rufino dos Santos. Entrevistador: Luciano Trigo. Entrevista concedida ao Portal G1, 29 de outubro de 2008.

Disponível em >http://g1.globo.com/platb/maquinadeescrever/2008/10/29/entrevistajoel-rufino-dos-santos/> Acesso em 24 de julho de 2019. 
SANTOS, Joel Rufino dos. Entrevista: Joel Rufino dos Santos. Entrevista concedida a Revista Democracia Viva, 2013. Disponível em: <http://www.canalibase.org.br/wpcontent/uploads/2015/09/dv_ibase_44_entrevista20-33.pdf >. Acesso em: 28 jul. 2019.

Entrevista com Joel Rufino dos Santos. Concedida a Amauri Mendes Pereira, Amilcar Araújo Pereira e Verena Alberti. Estudos Históricos, Rio de Janeiro, vol. 26, $\mathrm{n}^{\circ}$ 52, p. 491-518, julho-dezembro de 2013. Disponível em: <http://www.scielo.br/scielo.php?script=sci_arttext\&pid=S0103-21862013000200012 >. Acesso em: 25 jul. 2019.

Joel Rufino, testemunho e reflexão sobre a Ditadura Militar no Brasil. Entrevista concedida ao Grupo Editorial Global no YouTube, 2014.

Disponível em 〈https://www.youtube.com/watch?v=U8qLH6o2nIo>. Acesso em: 25 jul. 2019.

Depoimento: um flash do negro sob a repressão da ditadura. In: SÃO PAULO, Comissão da Verdade "Rubens Paiva". Relatório - Tomo I - Parte II - Perseguição à População e ao Movimento Negros, 2015. Disponível em http://comissaodaverdade.al.sp.gov.br/relatorio/. Acesso em: 29 jul. 2019.

SELIGMANN-SILVA, Márcio. Narrar o trauma - a questão dos testemunhos de catástrofes históricas. Psic. Clin., Rio De Janeiro, Vol.15, n. 2, 2008, p. 65-82.

SINGER, Paul. O processo econômico. In: REIS, Daniel Aarão (Coord). Modernização, ditadura e democracia: 1964-2010. Rio de Janeiro: Objetiva, 2014.

TEGA, Danielle. Tramas da memória: um estudo de testemunhos femininos sobre as ditaduras militares no Brasil e na Argentina. Tese (Doutorado) - Universidade Estadual de Campinas. Campinas-SP, 2015.

VARGAS, Mariluce Cardoso de. O testemunho e suas formas: historiografia, literatura, documentário (Brasil, 1964-2017). Tese (doutorado) - Universidade Federal do Rio Grande do Sul, Porto Alegre, 2018. 